\title{
Article \\ Effect of Copper, Zinc, and Selenium on the Migration of Bovine Neutrophils
}

\author{
Hai Wang ${ }^{1,2}$, Guanxin Lv ${ }^{1,2}$, Shuai Lian ${ }^{1,2}$, Jianfa Wang ${ }^{1,2}$ and Rui Wu ${ }^{1,2, *(D)}$ \\ 1 College of Animal Science and Veterinary Medicine, Heilongiang Bayi Agricultural University, \\ Daqing 163319, China; whdota@foxmail.com (H.W.); lvarron@foxmail.com (G.L.); \\ lianlianshuai@163.com (S.L.); wjflw@sina.com (J.W.) \\ 2 Heilongiang Provincial Key Laboratory of Prevention and Control of Bovine Diseases, Daqing 163319, China \\ * Correspondence: fuhewu@126.com; Tel.: +86-459-6819188
}

check for updates

Citation: Wang, H.; Lv, G.; Lian, S.; Wang, J.; Wu, R. Effect of Copper, Zinc, and Selenium on the Migration of Bovine Neutrophils. Vet. Sci. 2021, 8, 281. https://doi.org/10.3390/ vetsci 8110281

Academic Editors: Xinwei Li, Guowen Liu and Patrick Butaye

Received: 2 October 2021

Accepted: 17 November 2021

Published: 19 November 2021

Publisher's Note: MDPI stays neutral with regard to jurisdictional claims in published maps and institutional affiliations.

Copyright: (c) 2021 by the authors. Licensee MDPI, Basel, Switzerland. This article is an open access article distributed under the terms and conditions of the Creative Commons Attribution (CC BY) license (https:// creativecommons.org/licenses/by/ $4.0 /)$.

\begin{abstract}
Neutrophils represent the first line of mammary gland defense against invading pathogens by transmigration across the mammary epithelial cell barrier. The effect of trace elements on the migration of bovine neutrophils is not clear. In this study, we investigated the effect of copper $(\mathrm{Cu}$; 0.5, 1.0 and $1.5 \mathrm{mg} / \mathrm{L}$ ), zinc (Zn; 1.0, 5.0 and $10 \mathrm{mg} / \mathrm{L}$ ) and selenium (Se; 0.1, 1.0 and $2.0 \mathrm{mg} / \mathrm{L}$ ) on the migration of bovine neutrophils by using a Transwell assay. The results showed that $\mathrm{Cu}, \mathrm{Zn}$ and Se promoted the number of neutrophils in the trans-mammary epithelium. With the increased concentration of $\mathrm{Cu}$ at $1.5 \mathrm{mg} / \mathrm{L}$, the number of neutrophils in the trans-mammary epithelium was increased significantly $(p<0.05)$. Zn $(5.0 \mathrm{mg} / \mathrm{L})$ and Se $(0.1 \mathrm{mg} / \mathrm{L})$ increased the migrated number of neutrophils $(p<0.01)$ to an extremely significant degree. These findings provided a theoretical and experimental basis for mammary gland immunity in dairy cows. Thus, we suggest that adding moderate amounts of different trace elements can improve the immune function of dairy cows.
\end{abstract}

Keywords: dairy cow; neutrophil; migration; trace elements

\section{Introduction}

Neutrophils are the main leukocyte cells and play an important role in the non-specific immune system of dairy cows. In the healthy mammary gland, neutrophils have a low concentration of cell population (from 5 to 20\%). When pathogens invade the bovine mammary gland, neutrophils are recruited to the mammary gland and execute important functions including phagocytosis, respiratory bursts, and the formation of an extracellular trapping network (NET) to kill pathogens [1-4]. The recruitment of neutrophils is a complex process including the following steps: tethering, rolling, adhesion, crawling, and trans-endothelial migration $[5,6]$. However, in the process of neutrophils performing their sterilization function, the reactive oxygen species (ROS), NETs and other cytotoxic effect molecules released by neutrophils will not only kill pathogens but also cause damage to the mammary gland itself $[7,8]$. It can be seen that neutrophils have a "double-edged sword" effect on the occurrence and development of dairy cows' mastitis. Several studies have shown that the promptness and magnitude of the initial recruitment of neutrophils by the infected mammary gland have a profound influence on the severity and outcome of mastitis [9-11]. That is, when the mammary gland is infected, neutrophils need to immediately migrate from the bloodstream to the site of infection to kill pathogens.

Several researchers have found an association between trace elements in bovine nutrition and the ability to resist infections [12-14]. Several studies have identified that cattle during the periparturient period have a depression in blood levels of copper $(\mathrm{Cu})$, zinc $(\mathrm{Zn})$, and selenium (Se). These nutrients are components of metal chelates, metalloproteins and various reductases. For example, $\mathrm{Cu}$ and $\mathrm{Zn}$ are components of $\mathrm{Cu} / \mathrm{Zn}$-superoxide dismutase $(\mathrm{Cu} / \mathrm{Zn}-\mathrm{SOD})$ against $\mathrm{ROS}$ [15]. $\mathrm{Zn}$ is essential and exists in almost all enzymes such as transferases, hydrolases, isomerases, oxidoreductases, and so on [16]. Similarly, 
many selenoprotein enzymes are related to immune function such as glutathione peroxidases (GPXs), thioredoxin reductases (TXNRDs), iodothyronine deiodinases (DIOs), and so on [17]. Since the 1980s, researchers have begun to study the effects of trace element deficiency on the function of neutrophils in animals. Boyne and Arthur found that neutrophils isolated from cattle fed $\mathrm{Se}, \mathrm{Cu}$, and $\mathrm{Se} / \mathrm{Cu}$-deficient diets were not affected the ability of the neutrophils to ingest $C$. albicans, but their ability to kill the ingested $C$. albicans was decreased [18]. Jones et al. and Olkowski et al. have similar study reports on sheep with $\mathrm{Cu}$ deficiency $[19,20]$. Percival et al. found that a lack of $\mathrm{Cu}$ can cause neutrophils reduction syndrome, which is manifested as a decrease in the number of neutrophils circulating in peripheral blood [21]. The transition metal $\mathrm{Zn}$ is an essential trace element indispensable for a suitable and sufficient immune response against pathogens. Studies have shown that Zn deficiency can affect neutrophils' function and reduce the chemotaxis of human neutrophils [22]. Bednarek et al. found adding $\mathrm{ZnSO}_{4}$ to the diet of calves can increase $\mathrm{Zn}$ levels in the liver and serum, enhance macrophages' random migration and change the proportion of neutrophils in peripheral blood [23]. Release of ROS is one of the ways that neutrophils kill invading pathogens. The content of ROS released and the ability to kill invading pathogens were significantly reduced in dairy cows with Se deficiency [24]. Supplementation of Se can effectively improve the chemotaxis and peroxide content of neutrophils [25]. Ndiweni and Finch found that neutrophils isolated from the blood of cows fed high levels of Se diet had a stronger ability to kill pathogens [26].

These studies suggest that the nutritional status of trace elements in dairy cows has an impact on the function of neutrophils. However, how trace elements $\mathrm{Cu}, \mathrm{Zn}$ and Se affect the migration of bovine neutrophils is unknown. Therefore, the objective of this work is to investigate the effect of $\mathrm{Cu}, \mathrm{Zn}$ and Se on the migration of neutrophils and provide useful information for the further study of trace elements on the function of neutrophils.

\section{Materials and Methods}

\subsection{Animals, Blood Collection and Neutrophil Isolation}

The test animals were selected from a sizeable intensive dairy farm in Daqing, Heilongjiang Province, China. Three healthy 2-year-old cows of similar body condition and at mid-lactation were randomly selected. All cows were healthy and did not exhibit any clinical signs of mastitis. Whole blood was collected from the cows via the middle tail vein. Neutrophils were isolated and purified by using the bovine peripheral blood neutrophil purification $\mathrm{kit}^{\circledR}$ (Solarbio, Beijing, China). Then, $4 \mathrm{~mL}$ Separate A, $2 \mathrm{~mL}$ Separate $\mathrm{C}$, and $2 \mathrm{~mL}$ sodium citrate anticoagulated whole blood were successively added into a $15 \mathrm{~mL}$ centrifuge tube, forming a liquid gradient. The mixture was then centrifuged at room temperature in an Eppendorf high-speed centrifuge at $900 \times g$ for $30 \mathrm{~min}$. After the centrifugation step, neutrophils were found in the lower gradient phase as a white ring. Neutrophils were extracted into a new $15 \mathrm{~mL}$ centrifuge tube and erythrocytes were lysed with Red Blood Cell Lysis Buffer. Then, the suspensions were centrifuged $(300 \times g, 5 \mathrm{~min})$ and washed three times; neutrophils were resuspended in Roswell Park Memorial Institute (RPMI) 1640 medium (Gibco, Grand Island, NY, USA) containing 10\% fetal bovine serum (FBS; Gibco Grand Island, NY, USA).

\subsection{Detection of Neutrophil Survival}

Separated neutrophils $(2 \mu \mathrm{L})$ were used to make a Giemsa-stained smear, which was checked for purity by a Nikon Eclipse TS100 inverted fluorescence microscope (Nikon, Tokyo, Japan). The obtained cell suspensions were stained with Trypan blue, and their concentration and viability were measured using Countess II Life Technologies Cell Counter (Countess $^{\mathrm{TM}}$ Invitrogen, Waltham, MA, USA).

\subsection{Cell Culture and Establishment of Epithelial Layer}

The bovine mammary epithelial cell (MAC-T) was obtained from Jilin University (Jilin, China). MAC-T cells were cultured in Dulbecco's Modified Eagle Medium: Nutrient 
Mixture F-12 (DMEM/F12; Gibco, Grand Island, NY, USA) medium supplemented with $10 \%$ FBS and $1 \%$ penicillin/streptomycin (P/S; Solarbio, Beijing, China) at $37{ }^{\circ} \mathrm{C}$ in a humidified atmosphere ( $5 \% \mathrm{CO}_{2} / 95 \%$ air). Cell migration assays were performed by using Transwell chambers (3.0 $\mu \mathrm{m}, 24$-well insert; Corning, Lowell, MA, USA). Using sterile forceps, the permeable supports were inserted into a sterile $25 \mathrm{~mm}$-deep tissue culture dish. Each Transwell permeable support was coated with $0.012 \mathrm{~g} / \mathrm{L}$ Collagen I (Corning, Lowell, MA, USA). Then, $50 \mu \mathrm{L}$ of the MAC-T cells suspension $\left(1 \times 10^{5}\right.$ cells) was added to each permeable support. The lid was carefully placed on the dish at $37^{\circ} \mathrm{C}$ with $5 \%$ $\mathrm{CO}_{2}$ for about $6 \mathrm{~h}$. The permeable supports were placed into a 24-well plate containing $0.2 \mathrm{~mL}$ DMEM/F12 per well. Then, $0.1 \mathrm{~mL}$ DMEM/F12 was added to the upper reservoir of each permeable support and incubated at $37^{\circ} \mathrm{C}$ with $5 \% \mathrm{CO}_{2}$. The medium was replaced every 2 days. After 3 days, the permeable supports were seeded with MAC-T, and the confluence of the cells was assessed (Figure 1A). The upper reservoir was filled with $0.3 \mathrm{~mL}$ DMEM/F12. The cells were sufficiently confluent when the medium did not equilibrate between the upper and lower reservoirs.

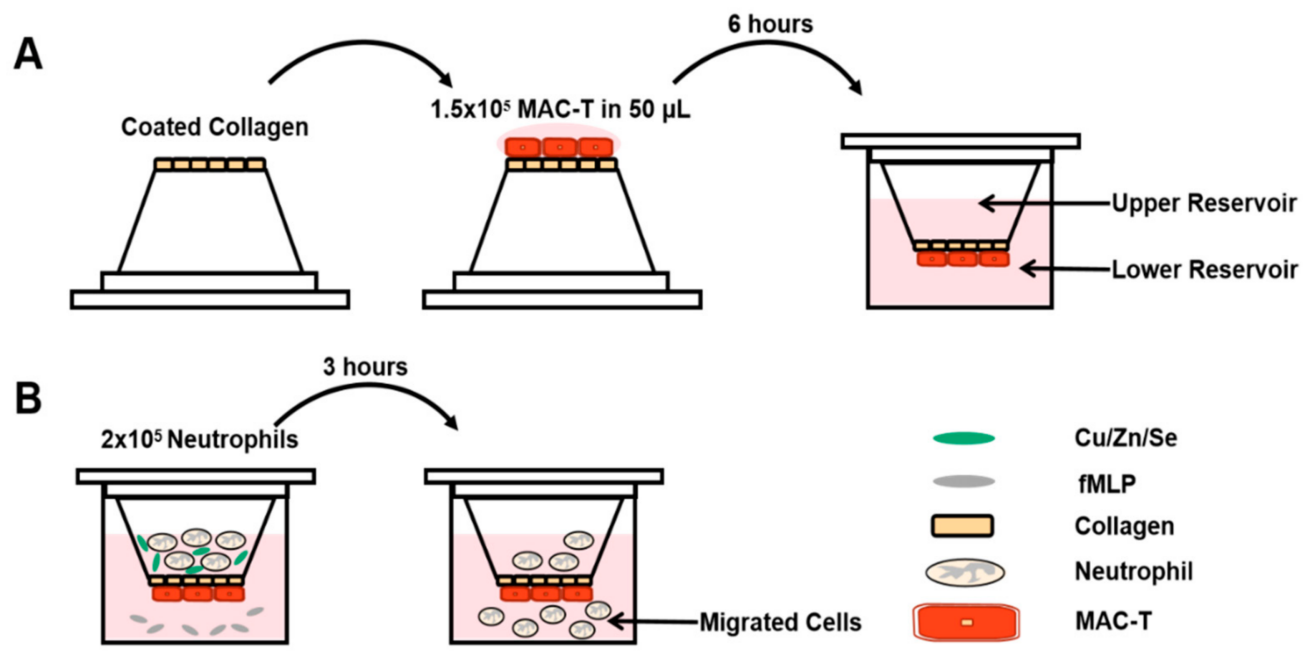

Figure 1. Schematic of experimental design. (A) MAC-T were seeded on inverted permeable supports; the supports were placed into a culture dish and incubated at $37^{\circ} \mathrm{C}$ to obtain about $90 \%$ confluence. (B) For selected experiments, neutrophils and additional agents (e.g., $\mathrm{Cu}$ ) were added to the upper reservoir; fMLP (100 nmol/L) in RPMI 1640 was used as the chemotactic solution in the lower reservoir. Migrated neutrophils were enumerated by the flow cytometer.

\subsection{Neutrophil Migration Assay}

A stock solution of N-Formyl-methionyl-leucyl-phenylalanine (fMLP; Sigma-Aldrich, St. Louis, MO, USA) was prepared at $10 \mu \mathrm{mol} / \mathrm{L}$ in DMSO (Solarbio, Beijing, China). $\mathrm{CuSO}_{4} \cdot 5 \mathrm{H}_{2} \mathrm{O}$ (Aladdin, Shanghai, China) was diluted in HBSS (Solarbio, Beijing, China) at a concentration of 1.0, 2.0, and $3.0 \mathrm{mg} / \mathrm{L}$. $\mathrm{ZnSO}_{4} \cdot 7 \mathrm{H}_{2} \mathrm{O}$ (Aladdin, Shanghai, China) was

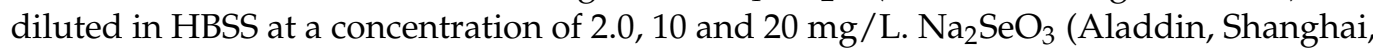
China) was diluted in HBSS at a concentration of $0.2,2.0$ and $4.0 \mathrm{mg} / \mathrm{L}$. Then, $990 \mu \mathrm{L}$ RPMI 1640 and $10 \mu \mathrm{L}$ fMLP were added into the lower chamber of Transwell chambers, and $100 \mu \mathrm{L}$ of cell suspension $\left(2 \times 10^{5}\right.$ Cells $)$ was added into the upper chamber. Three chambers were selected and $100 \mu \mathrm{L}$ HBSS was added to each upper chamber as the blank control group.

To other chambers, $100 \mu \mathrm{L}$ of different concentrations of $\mathrm{Cu} / \mathrm{Zn} /$ Se dilutions were added, forming the experimental group. The Transwell chambers were placed in an incubator with $5 \% \mathrm{CO}_{2}$ and incubated at $37^{\circ} \mathrm{C}$ for $2 \mathrm{~h}$ (Figure 1B). The number of neutrophils that migrated to the lower chamber was measured with flow cytometry (Beckman Coulter, CA, USA). In brief, the fluid in the lower chamber was collected into the FACS tube and 
cells were counted using a flow cytometer and analyzed using FlowJo software (FlowJo LLC, version 10.6.0.). All experiments were repeated at least three times.

\subsection{Statistical Analysis}

All data were presented as the mean \pm SEM deviation and analyzed using the GraphPad 8.0 software. One-way ANOVA and the least significant difference (LSD) test were used for parameter estimation and hypothesis testing. Significant differences were established at $p<0.05$ or $p<0.01$.

\section{Results}

\subsection{Neutrophil Isolation}

Neutrophils were isolated as per the manufacturer's instructions, as described previously. The morphology of neutrophils is presented in Figure 2. The purity rate and the survival rate were both $>90 \%$, which was in accordance with the requirement for subsequent experiments and all experiments were based on this condition.

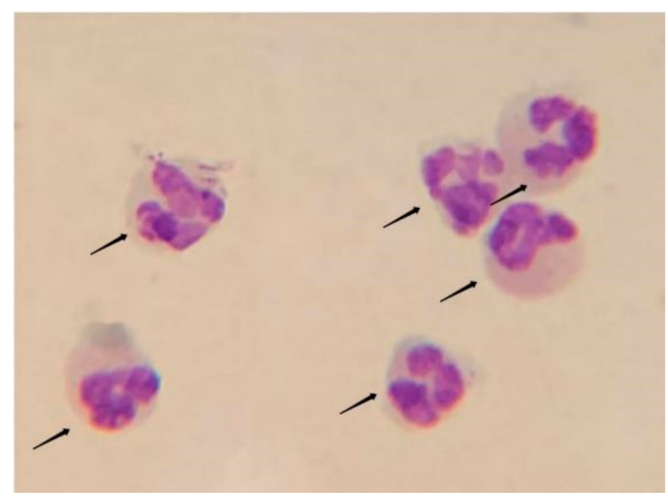

Figure 2. Morphology of neutrophils. Neutrophils were stained with Wright-Giemsa. Black arrows indicate neutrophil.

\subsection{Effects of $\mathrm{Cu}$ on the Migration of Neutrophils across Mammary Epithelial Cells}

The results of $\mathrm{Cu}$ on the migration of neutrophils are shown in Figure 3. The lower concentration of $\mathrm{Cu}$ had no significant effect on the number of neutrophils in the transmammary epithelium $(p>0.05)$. However, when the concentration of $\mathrm{Cu}$ was $1.5 \mathrm{mg} / \mathrm{mL}$, the number of neutrophils in the trans-mammary epithelium was increased significantly $(p<0.05)$.

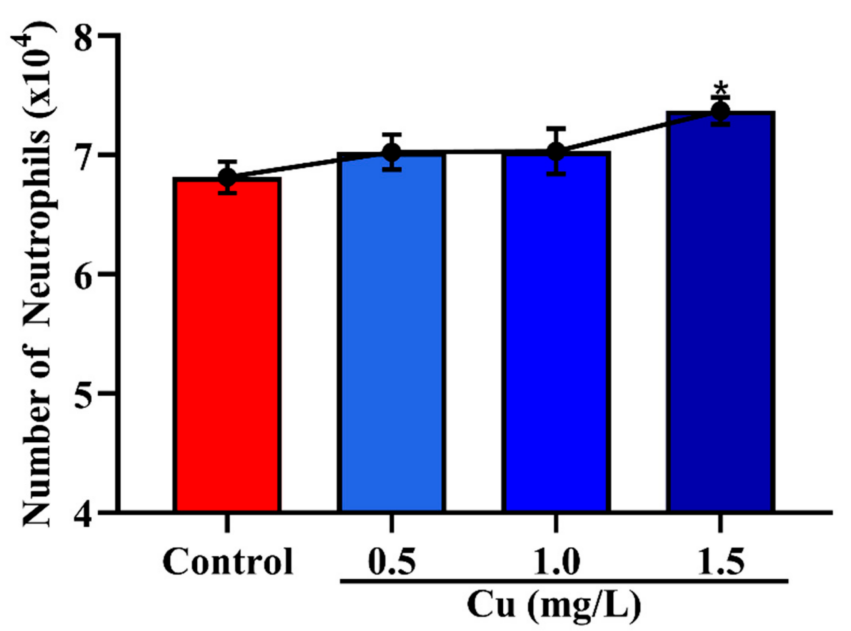

Figure 3. Effects of $\mathrm{Cu}$ on the migration of neutrophils in the trans-mammary epithelium. ${ }^{*} p<0.05$ between the different concentrations of $\mathrm{Cu}(0.5,1.0$ and $1.5 \mathrm{mg} / \mathrm{L})$ group and the control group in the same batch. Each value represents the mean \pm SEM, $n=6$. 


\subsection{Effects of Zn on the Migration of Neutrophils across Mammary Epithelial Cells}

The results of $\mathrm{Zn}$ on the migration of neutrophils are shown in Figure 4. The results showed that $\mathrm{Zn}$ promoted the number of neutrophils in the trans-mammary epithelium in a dose-dependent manner. The number of neutrophils in the trans-mammary epithelium was increased extremely significantly $(p<0.01)$, when the concentration of Zn was $5.0 \mathrm{mg} / \mathrm{mL}$.

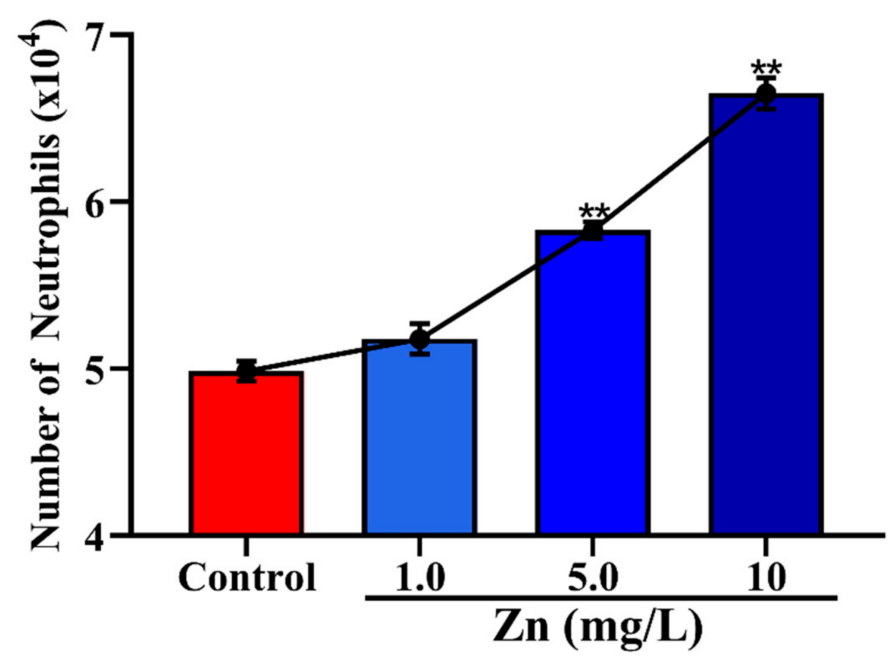

Figure 4. Effects of $\mathrm{Zn}$ on the migration of neutrophils in the trans-mammary epithelium. ${ }^{* *} p<0.01$ between the different concentrations of $\mathrm{Zn}(1.0,5.0$ and $10 \mathrm{mg} / \mathrm{L})$ group and the control group in the same batch. Each value represents the mean \pm SEM, $n=6$.

\subsection{Effects of Se on the Migration of Neutrophils across Mammary Epithelial Cells}

The results of Se on the migration of neutrophils are shown in Figure 5. The results showed that different concentrations of Se can promote the number of neutrophils in the trans-mammary epithelium in a dose-dependent manner. When the concentration of Se was $0.1 \mathrm{mg} / \mathrm{mL}$, the number of neutrophils in the trans-mammary epithelium increased significantly $(p<0.01)$.

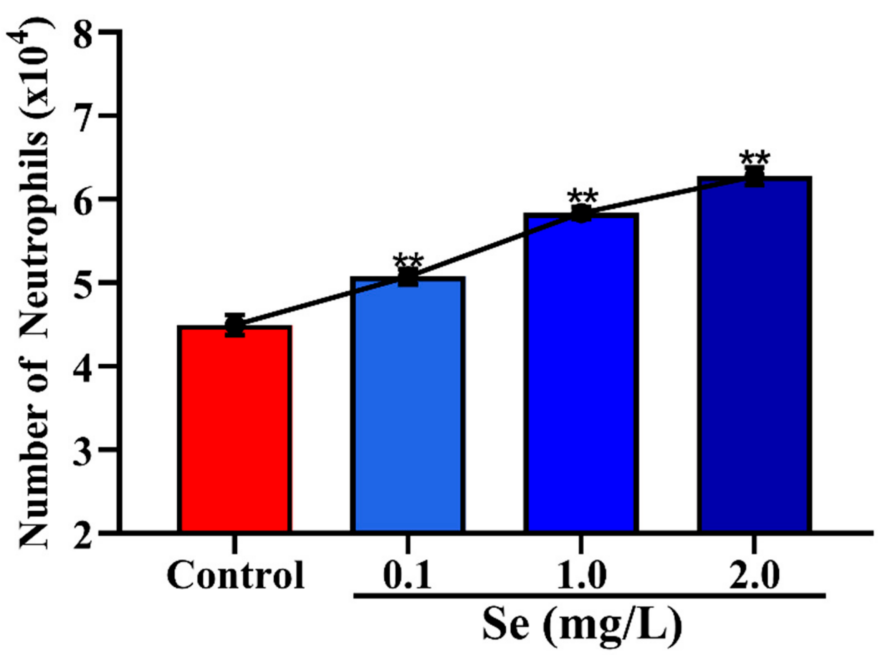

Figure 5. Effects of Se on the migration of neutrophils in the trans-mammary epithelium. ${ }^{* *} p<0.01$ between the different concentrations of Se $(0.1,1.0$ and $2.0 \mathrm{mg} / \mathrm{L})$ group and the control group in the same batch. Each value represents the mean \pm SEM, $n=6$.

\section{Discussion}

Neutrophils represent the first line of mammary gland defense against invading pathogens by transmigration across the mammary epithelial cell barrier [5]. Admittedly, 
neutrophils' infiltration of the mammary gland is critical for killing pathogens, but aberrant neutrophil accumulation into mammary gland tissue also causes damage, which is called the "double-edged sword" effect. The recruitment of neutrophils into the mammary gland is a multiple-step process and highly regulated by many proteins such as selectins, integrins, intercellular adhesion molecules (ICAM), and so on [27]. Studies have shown that dietary $\mathrm{Cu}$ deficiency augments neutrophil accumulation in the lung and reduces the deformability of neutrophils by promoting F-actin polymerization [28]. Cu deficiency also promoted the interactions between neutrophil and endothelial cells by increasing the expression of CD11b and ICAM-1 $[29,30]$. The lower and normal concentrations of $\mathrm{Cu}(0.5$ and $1.0 \mathrm{mg} / \mathrm{L})$ had no significant effect on the number of neutrophils in the trans-mammary epithelium $(p>0.05)$. With the increased concentration of $\mathrm{Cu}$ at $1.5 \mathrm{mg} / \mathrm{L}$, the number of neutrophils in the trans-mammary epithelium was increased significantly $(p<0.05)$. This result might be because the $\mathrm{Cu}$ could promote the deformability of neutrophils. However, the normal physiological concentration of $\mathrm{Cu}$ is $0.7 \sim 0.9 \mathrm{mg} / \mathrm{L}$ in bovine serum and $\mathrm{Cu}$ excess may be even more harmful and can result in serious toxicity [18].

$\mathrm{Zn}$ is an essential ion for animal nutrition and development and plays an important role in cell functions, such as protein synthesis and enzymatic regulation, but excess $\mathrm{Zn}$ induces drastic toxicity symptoms. Past studies have repeatedly shown that immune cells are affected by free intracellular $\mathrm{Zn}$ and impaired cell migration in clinical and experimentally induced Zn deficiency [16,31]. In bovine serum, the normal physiological concentration of $\mathrm{Zn}$ is $0.7 \sim 1.3 \mathrm{mg} / \mathrm{L}$ [32]. Our findings on $\mathrm{Zn}$ are consistent with previous reports that supra-physiological concentrations of $\mathrm{Zn}(5 \mathrm{mg} / \mathrm{L})$ can promote the migration of neutrophils $(p<0.01)$. One possible explanation is that $\mathrm{Zn}$ acts as a chemoattractant and enhances chemotaxis toward fMLP in rat neutrophils [33]. However, those findings could not be reproduced in human neutrophils. This phenomenon can be attributed to the species difference and the distinct activation states of resting and primed cells.

Se is one of the essential trace elements, with various important biological functions in mammals. It is a necessary component of numerous enzymes that are involved in redox reactions and this antioxidative function causes Se to protect immune cells from oxidative stress caused by respiratory burst. In bovine serum, the normal physiological concentration of Se is over $0.08 \mathrm{mg} / \mathrm{L}$ [18]. Innate immune cell functions have been shown to be impacted by Se levels. However, less information is available regarding Se levels and neutrophil functions. Selenoprotein $\mathrm{K}(\mathrm{SelK})$ is a transmembrane protein and is highly expressed in immune cells. Studies show that mice with SelK-knockout reduced the migration of neutrophils $[17,34]$. This effect is likely caused by the decreased calcium flux. In this study, we found that Se can promote the trans-epithelial migration of neutrophils $(p<0.01)$, which is characterized by an increase in Se concentration (from 0.1 to $2.0 \mathrm{mg} / \mathrm{L}$ ). We hypothesize that Se may increase the intracellular calcium flux of neutrophils, which enhanced neutrophils' random motility.

In summary, our results indicated that trace elements $\mathrm{Cu}, \mathrm{Zn}$ and Se could promote the trans-mammary epithelium migration of neutrophils in vitro. These findings provide a theoretical and experimental basis for mammary gland immunity in dairy cows. Thus, we suggest that adding moderate amounts of different trace elements may improve the immune function of dairy cows.

Author Contributions: Conceptualization, J.W. and S.L.; methodology, H.W.; G.L. software, validation and formal analysis H.W. and G.L.; writing-original draft preparation, H.W.; writing-review and editing, J.W. and S.L.; visualization, G.L.; supervision, R.W.; project administration, R.W.; funding acquisition, R.W. All authors have read and agreed to the published version of the manuscript.

Funding: This work was funded by the Natural Science Foundation of China (31972747, 31772698 and 32172937), the Natural Science Foundation of Heilongjiang Province (c2018043) and Natural Science Foundation of Heilongjiang Province of China (YQ2019C014).

Institutional Review Board Statement: All procedures were performed according to guidelines and regulations of the Heilongjiang Bayi Agricultural University and animals were approved by 
the Laboratory Animal Ethics Committee College of Animal Science and Veterinary Medicine, Heilongjiang Bayi Agricultural University (No. BYAU20191121), approval date is 5 December 2019.

Informed Consent Statement: The informed consent was obtained from the owner of dairy farm in this study.

Data Availability Statement: The data presented in this study are available in the manuscript.

Acknowledgments: We thank the teachers and students of the College of Animal Science and Veterinary Medicine, Heilongjiang Bayi Agricultural University, for their help.

Conflicts of Interest: Authors declare no conflict of interest for this article.

\section{References}

1. Nathan, C. Neutrophils and immunity: Challenges and opportunities. Nat. Rev. Immunol. 2006, 6, 173-182. [CrossRef]

2. Segal, A.W. How neutrophils kill microbes. Annu. Rev. Immunol. 2005, 23, 197-223. [CrossRef]

3. Amulic, B.; Cazalet, C.; Hayes, G.L.; Metzler, K.D.; Zychlinsky, A. Neutrophil function: From mechanisms to disease. Annu. Rev. Immunol. 2012, 30, 459-489. [CrossRef]

4. Brinkmann, V.; Reichard, U.; Goosmann, C.; Fauler, B.; Uhlemann, Y.; Weiss, D.S.; Weinrauch, Y.; Zychlinsky, A. Neutrophil extracellular traps kill bacteria. Science 2004, 303, 1532-1535. [CrossRef] [PubMed]

5. Filippi, M.D. Neutrophil transendothelial migration: Updates and new perspectives. Blood 2019, 133, 2149-2158. [CrossRef] [PubMed]

6. Vestweber, D. How leukocytes cross the vascular endothelium. Nat. Rev. Immunol. 2015, 15, 692-704. [CrossRef] [PubMed]

7. Kaplan, M.J.; Radic, M. Neutrophil extracellular traps: Double-edged swords of innate immunity. J. Immunol. 2012, 189, 2689-2695. [CrossRef]

8. Jaganjac, M.; Cipak, A.; Schaur, R.J.; Zarkovic, N. Pathophysiology of neutrophil-mediated extracellular redox reactions. Front. Biosci. Landmark Ed. 2016, 21, 839-855. [CrossRef]

9. Rainard, P.; Riollet, C. Mobilization of neutrophils and defense of the bovine mammary gland. Reprod. Nutr. Dev. 2003, 43, 439-457. [CrossRef]

10. Herbelin, C.; Poutrel, B.; Gilbert, F.B.; Rainard, P. Immune recruitment and bactericidal activity of neutrophils in milk of cows vaccinated with staphylococcal alpha-toxin. J. Dairy Sci. 1997, 80, 2025-2034. [CrossRef]

11. Colditz, I.G.; Watson, D.L. Effect of immunisation on the early influx of neutrophils during staphylococcal mastitis in ewes. Res. Vet. Sci. 1982, 33, 146-151. [CrossRef]

12. Suttle, N.F.; Jones, D.G. Recent developments in trace element metabolism and function: Trace elements, disease resistance and immune responsiveness in ruminants. J. Nutr. 1989, 119, 1055-1061. [CrossRef] [PubMed]

13. Wintergerst, E.S.; Maggini, S.; Hornig, D.H. Contribution of selected vitamins and trace elements to immune function. Ann. Nutr. Metab. 2007, 51, 301-323. [CrossRef]

14. Bicalho, M.L.; Lima, F.S.; Ganda, E.K.; Foditsch, C.; Meira, E.J.; Machado, V.S.; Teixeira, A.G.; Oikonomou, G.; Gilbert, R.O.; Bicalho, R.C. Effect of trace mineral supplementation on selected minerals, energy metabolites, oxidative stress, and immune parameters and its association with uterine diseases in dairy cattle. J. Dairy Sci. 2014, 97, 4281-4295. [CrossRef] [PubMed]

15. Valko, M.; Rhodes, C.J.; Moncol, J.; Izakovic, M.; Mazur, M. Free radicals, metals and antioxidants in oxidative stress-induced cancer. Chem. Biol. Interact. 2006, 160, 1-40. [CrossRef] [PubMed]

16. Wessels, I.; Maywald, M.; Rink, L. Zinc as a Gatekeeper of Immune Function. Nutrients 2017, 9, 1286. [CrossRef] [PubMed]

17. Avery, J.C.; Hoffmann, P.R. Selenium, Selenoproteins, and Immunity. Nutrients 2018, 10, 1203. [CrossRef] [PubMed]

18. Boyne, R.; Arthur, J.R. Effects of selenium and copper deficiency on neutrophil function in cattle. J. Comp. Pathol. 1981, 91, 271-276. [CrossRef]

19. Jones, D.G.; Suttle, N.F. Some effects of copper deficiency on leucocyte function in sheep and cattle. Res. Vet. Sci. 1981, 31, 151-156. [CrossRef]

20. Olkowski, A.A.; Gooneratne, S.R.; Christensen, D.A. Effects of diets of high sulphur content and varied concentrations of copper, molybdenum and thiamine on in vitro phagocytic and candidacidal activity of neutrophils in sheep. Res. Vet. Sci. 1990, $48,82-86$. [CrossRef]

21. Percival, S.S. Neutropenia caused by copper deficiency: Possible mechanisms of action. Nutr. Rev. 1995, 53, 59-66. [CrossRef]

22. Vruwink, K.G.; Keen, C.L.; Gershwin, M.E.; Mareschi, J.P.; Hurley, L.S. The Effect of Experimental Zinc Deficiency on Development of the Immune System. In Nutrient Modulation of the Immune Response; CRC Press: New York, NY, USA, 2020; pp. 263-280.

23. Bednarek, D.; Kondracki, M.; Krasucki, J. The effect of zinc on mineral, hematological and immunological indices in calves. Pol. Arch. Weter 1991, 31, 129-140. [PubMed]

24. Rizzo, A.; Pantaleo, M.; Mutinati, M.; Minoia, G.; Trisolini, C.; Ceci, E.; Sciorsci, R.L. Blood and milk oxidative status after administration of different antioxidants during early postpartum in dairy cows. Res. Vet. Sci. 2013, 95, 1171-1174. [CrossRef]

25. Mehdi, Y.; Dufrasne, I. Selenium in Cattle: A Review. Molecules 2016, 21, 545. [CrossRef] [PubMed]

26. Ndiweni, N.; Finch, J.M. Effects of in vitro supplementation with alpha-tocopherol and selenium on bovine neutrophil functions: Implications for resistance to mastitis. Vet. Immunol. Immunopathol. 1996, 51, 67-78. [CrossRef] 
27. Williams, M.R.; Azcutia, V.; Newton, G.; Alcaide, P.; Luscinskas, F.W. Emerging mechanisms of neutrophil recruitment across endothelium. Trends Immunol. 2011, 32, 461-469. [CrossRef] [PubMed]

28. Gordon, S.A.; Lominadze, D.; Saari, J.T.; Lentsch, A.B.; Schuschke, D.A. Impaired deformability of copper-deficient neutrophils. Exp. Biol. Med. 2005, 230, 543-548. [CrossRef] [PubMed]

29. Lominadze, D.; Saari, J.T.; Percival, S.S.; Schuschke, D.A. Proinflammatory effects of copper deficiency on neutrophils and lung endothelial cells. Immunol. Cell Biol. 2004, 82, 231-238. [CrossRef]

30. Schuschke, D.A.; Percival, S.S.; Lominadze, D.; Saari, J.T.; Lentsch, A.B. Tissue-specific ICAM-1 expression and neutrophil transmigration in the copper-deficient rat. Inflammation 2002, 26, 297-303. [CrossRef] [PubMed]

31. Haase, H.; Rink, L. Zinc signals and immune function. Biofactors 2014, 40, 27-40. [CrossRef]

32. Puls, R. Mineral Levels in Animal Health: Diagnostic Data, 2nd ed.; Sherpa International: Clearbrook, BC, Canada, 1994.

33. Hasan, R.; Rink, L.; Haase, H. Chelation of Free $\mathrm{Zn}^{2+}$ Impairs Chemotaxis, Phagocytosis, Oxidative Burst, Degranulation, and Cytokine Production by Neutrophil Granulocytes. Biol. Trace Elem. Res. 2016, 171, 79-88. [CrossRef] [PubMed]

34. Huang, Z.; Rose, A.H.; Hoffmann, P.R. The role of selenium in inflammation and immunity: From molecular mechanisms to therapeutic opportunities. Antioxid. Redox Signal. 2012, 16, 705-743. [CrossRef] [PubMed] 